\title{
Noise Monitoring in the City of São Luís, Brazil
}

Diego Rosa dos Santos ${ }^{1}$, Sérgio Fernando Saraiva da Silva ${ }^{2}$, Will Ribamar Mendes Almeida ${ }^{3}$, Airton Garcia da Silva Santos ${ }^{4}$, Wilhamy Coimbra de Araújo ${ }^{5}$ and Paulo Cesar Mendes Villis ${ }^{6}$

${ }^{1}$ Universidade CEUMA - UniCEUMA, São Luís-Maranhão, Brasil profdiegorosa@gmail.com

${ }^{2}$ Universidade CEUMA - UniCEUMA, São Luís-Maranhão, Brasil sergio.silva@ceuma.br

${ }^{3}$ Universidade CEUMA - UniCEUMA, São Luís-Maranhão, Brasil will.almeida@ceuma.br

${ }^{4}$ Universidade CEUMA - UniCEUMA, São Luís-Maranhão, Brasil airtongharcia@yahoo.com.br

${ }^{5}$ Universidade CEUMA - UniCEUMA, São Luís-Maranhão, Brasil wilhamy.eng@gmail.com

${ }^{6}$ Universidade CEUMA - UniCEUMA, São Luís-Maranhão, Brasil paulo.villis@ceuma.br

\begin{abstract}
The noise generated by vehicular traffic is a major source of discomfort for urban residents and directly affects their quality of life. This study performed the monitoring of urban noise in the city of São Luis, Brazil. The data were collected at 25 sampling points throughout the city over a period of 6 months-1 week per month from Monday to Sunday between the hours of 11:00 and 13:00. The results showed that 23 points were above the limits established by NBR 10151/00. The analysis of variance showed significant differences between the points. Therefore, it is evident that the population is exposed to high levels of noise capable of generating public health problems. The two points within the NBR limits were recorded in an area with dense vegetation, showing the importance of the preservation of the vegetation.
\end{abstract}

Keywords: Noise; Traffic; Vegetation 


\section{Introdution}

There are many existing environmental problems that must be addressed (de Lacerda, Magni, Morata, Marques, \& Zannin, 2005). Large cities are suffering from the major consequences of urban growth (World Health Organization -WHO, 2011), which include a range of problems that affect residents' quality of life and contribute to environmental degradation (Alves, Silva, \& Remoaldo, 2015).

Environmental degradation is caused by various types of pollution (Bachmann, Carneiro, \& Espejo, 2013); one of these is the noise pollution present in the daily lives of people living in large cities (Brito, 2017; Mendonça, Suriano, Lucas De Souza, \& Viviani, 2013). Increases in noise pollution can come from various sources, such as vehicle traffic, leisure activities, and certain work environments (Zannin, Calixto, Diniz, Ferreira, \& Schuhli, 2002).

Noise from vehicular traffic, caused by tire and road contact, and increased speed that has resulted from improved engine conservation and aerodynamics (Hanson et al., 2005), is one of the main sources of noise pollution (Zannin et al., 2002). Vehicle noise contributes a great deal to the soundscape of big cities (Ravinder \& Belachew, 2014).

In Europe, countries are increasingly looking for innovative ways to reduce traffic noise emissions through the European Directive 2002/49/EC (EC, 2002), and have implemented noise maps for enhanced environmental management and control. In Brazil, data from the National Association of Public Transport (ANTP) show a ratio of 122 inhabitants per vehicle in 2003. Current data for São Luís, the capital of Maranhão, show an approximate ratio of 4 inhabitants per vehicle, which increases the contribution of vehicles to urban noise (IBGE, 2017).

It has been established that an increase in urban noise exposes the population to a greater risk of diseases related to high noise levels (da Paz, Ferreira, \& Zannin, 2005). When noise rises above levels permitted by Brazilian legislation, it can cause irritability, altered metabolism, changes in sleep patterns, and a lack of concentration in residents (de Lacerda, Figueiredo, Massarolo Neto, \& Marques, 2010).

A survey carried out by Lacerda et al. (de Lacerda et al., 2005) in the city of Curitiba, which aimed to identify the psychosocial reactions of the population to environmental noise, showed that the sources that most disturb residents are traffic noise ( $66.8 \%$ of the 892 interviewed), followed by neighbors (33.1\%). The results of a study conducted in the city of Aracaju showed that high traffic noise levels significantly affected the population (Guedes \& Bertoli, 2014).

The Brazilian Association of Technical Standards' (ABNT) directive NBR 10151/00 (ABNT, 2000) establishes the conditions for noise assessment in inhabited areas, with procedures and classifications specific to the type of area being studied. It also establishes the Level of Evaluation Criterion (NCA) for the daytime and nighttime periods.

In light of the heavy traffic in São Luís, this study monitored urban noise in the city by measuring noise levels at established points and comparing their values to the limits set by current legislation. 


\section{Materials and methods}

\subsection{Study Area Characterization}

The study area comprises the urban perimeter of the city of São Luís (Figure 1), capital of the state of Maranhão. According to data from the Brazilian Institute of Geography and Statistics (IBGE), the city, located at latitude $\mathrm{S} 2^{\circ} 31^{\prime}$ and longitude $\mathrm{W} 44^{\circ} 16^{\prime}$, covers an area of $834,785 \mathrm{~km}^{2}$, and is home to $1,091,868$ inhabitants in 233 neighborhoods, subdivisions, and residential complexes.

Figure 1 - Location of the municipality of São Luís. The location of the areas delimited for the development of urban acoustic monitoring (in-detail)

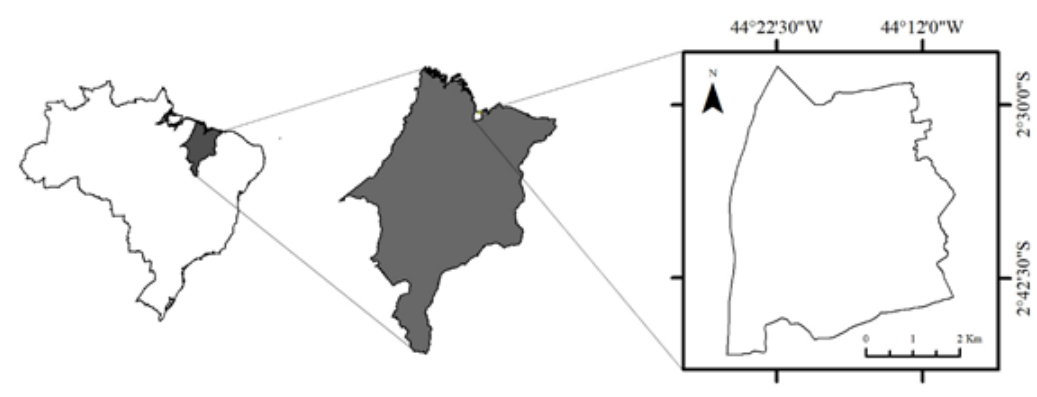

Twenty-five sampling points were selected to evaluate the noise levels in different types of areas, as shown in Figure 2.

Figure 2 - Location of the sampling points

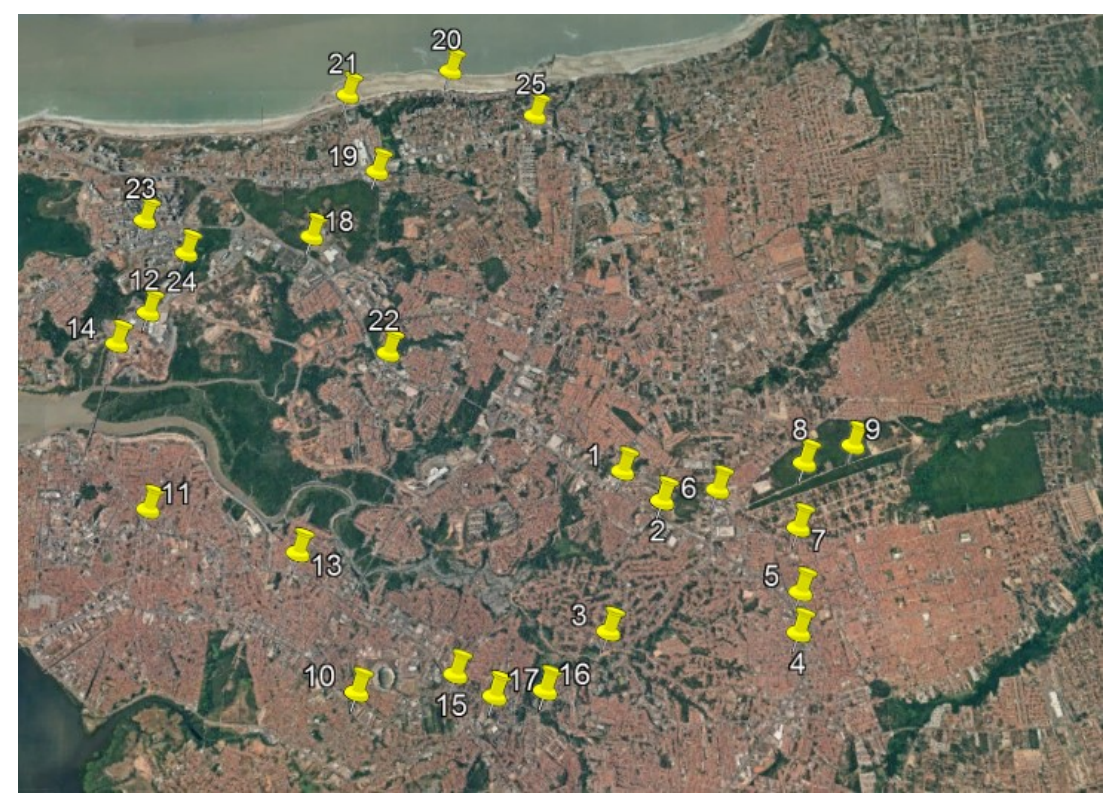

Each point was classified by area according to NBR 10151/00. Table 1 presents the NCA for each area, which is the maximum level allowed for the daytime period. 
Table 1 - Classification of points and NCA according to NBR 10151/00

\begin{tabular}{l|l|c}
\hline $\begin{array}{l}\text { Sampling } \\
\text { Points }\end{array}$ & Classification ABNT 10151/00 & $\begin{array}{c}\text { NCA - Daytime } \\
\text { (dBA) }\end{array}$ \\
\hline 1 & Mixed area, with commercial and administrative functions & 60,0 \\
\hline 2 & Strictly residential urban or hospital or school area & 50,0 \\
\hline 3 & Strictly residential urban or hospital or school area & 50,0 \\
\hline 4 & Strictly residential urban or hospital or school area & 50,0 \\
\hline 5 & Mixed area, with commercial and administrative functions & 60,0 \\
\hline 6 & Mixed area, with commercial and administrative functions & 60,0 \\
\hline 7 & Strictly residential urban or hospital or school area & 50,0 \\
\hline 8 & Site areas and farm & 40,0 \\
\hline 9 & Site areas and farm & 40,0 \\
\hline 10 & Mixed, predominantly residential area & 55,0 \\
\hline 11 & Mixed area, with commercial and administrative functions & 60,0 \\
\hline 12 & Mixed area, with commercial and administrative functions & 60,0 \\
\hline 13 & Mixed area, with commercial and administrative functions & 60,0 \\
\hline 14 & Mixed, predominantly residential area & 55,0 \\
\hline 15 & Mixed, predominantly residential area & 55,0 \\
\hline 16 & Mixed area, with commercial and administrative functions & 60,0 \\
\hline 17 & Strictly residential urban or hospital or school area & 50,0 \\
\hline 18 & Mixed area, with commercial and administrative functions & 60,0 \\
\hline 19 & Strictly residential urban or hospital or school area & 50,0 \\
\hline 20 & Mixed area with recreational functions & 65,0 \\
\hline 21 & Mixed, predominantly residential area & 55,0 \\
\hline 22 & Mixed area, with commercial and administrative functions & 60,0 \\
\hline 23 & Mixed area, with commercial and administrative functions & 60,0 \\
\hline 24 & Site areas and farm & 50,0 \\
\hline 25 & Strictly residential urban or hospital or school area & 50,0 \\
\hline & & \\
\hline
\end{tabular}

\subsection{Measuring Urban Noise}

For noise measurements, we used calibrated InstruTherm sound pressure meters (model DEC 460), with the weighting curve adjusted to A to represent the threshold of human hearing, and fast response mode activated.

Noise measurements were conducted for a total of six months in May, July, September, and November of 2017, and in January and March of 2018. Measurements were carried out during one week (from Monday to Sunday) of the month, always between the hours of 11:00 to 13:00. To accurately assess acoustic behavior, all measurements were taken at the same time during the study months.

NBR 10151/00 stipulates that each point should have a measurement time of 5 minutes and the value of the sound pressure level must be recorded every 5 seconds - a total of 60 readings per point on each measurement day. The NBR 10151/00 also presents an equation for the calculation of the equivalent sound pressure level (Leq), as seen in Equation 1.

$$
L_{\text {Aeq }}=10 \log \frac{1}{n} \sum_{i=1}^{n} 10^{\frac{L_{i}}{10}}
$$

where $n$ is the total number of readings, $\mathrm{L}_{i}$ is the sound pressure level in $\mathrm{dB}(\mathrm{A})$ read in rapid response (fast) every $5 \mathrm{~s}$ throughout the measurement time. The standard deviation and the coefficient of variation were 
calculated, and the ANOVA and Tukey Significant Difference (TSD) tests were performed to verify the significance of the data.

\section{Results and discussion}

Leq was calculated for all sampling points, as was the mean of the days of the week of each month (Table 2) and their respective standard deviations. The ANOVA test was performed at $p<0.05$ and significant differences were found between the calculated means. The averages followed by the same letter do not differ statistically from each other, showing which sampling points are statistically the same.

Table 2 - Equivalent sound pressure levels (Leq A) for the monitoring months

\begin{tabular}{|c|c|c|c|c|c|c|}
\hline \multirow{2}{*}{$\begin{array}{l}\text { Sampling } \\
\text { Points }\end{array}$} & \multicolumn{6}{|c|}{ Monitoring period* } \\
\hline & May/17 & July/17 & September/17 & November/17 & January/18 & March/18 \\
\hline 1 & $71,1^{\text {abcde }} \pm 1,0$ & $72,5^{\mathrm{abc}} \pm 1,3$ & $73,6^{\mathrm{ab}} \pm 1,2$ & $70,8^{\mathrm{abc}} \pm 1,5$ & $71,4^{\text {abcd }} \pm 1,4$ & $72,4^{\mathrm{ab}} \pm 2,0$ \\
\hline 2 & $63,9^{\text {ghi }} \pm 2,4$ & $63,3^{\mathrm{gh}} \pm 3,1$ & $66,2^{\mathrm{h}} \pm 1,5$ & $67,0^{\text {cdef }} \pm 1,2$ & $67,0^{\mathrm{efg}_{ \pm 3,3}}$ & $66,5^{\mathrm{de}} \pm 2,8$ \\
\hline 3 & $63,5^{\text {hi }} \pm 2,8$ & $61,0^{\text {hi }} \pm 3,0$ & $60,9^{i} \pm 2,6$ & $56,5^{\mathrm{g}} \pm 4,3$ & $57,5^{i} \pm 2,9$ & $59,5^{f} \pm 2,6$ \\
\hline 4 & $60,{ }^{1} \pm 2,5$ & $59,7^{i} \pm 3,9$ & $59,5^{i} \pm 2,1$ & $65,4^{\mathrm{ef}} \pm 1,4$ & $59,7^{\mathrm{hi}_{1}} \pm 2,7$ & $60,7^{\mathrm{f}} \pm 2,1$ \\
\hline 5 & $73,2^{\text {abcd }} \pm 0,7$ & $73,0^{\mathrm{ab}} \pm 0,9$ & $72,2^{\mathrm{abc}} \pm 1,7$ & $73,1^{\mathrm{a}} \pm 1,7$ & $71,0^{\mathrm{abcd}} \pm 2,0$ & $72,4^{\mathrm{ab}} \pm 2,3$ \\
\hline 6 & $74,8^{\mathrm{ab}} \pm 1,9$ & $74,0^{\mathrm{a}} \pm 0,9$ & $73,6^{\mathrm{ab}} \pm 1,5$ & $73,7^{\mathrm{a}} \pm 1,0$ & $73,2^{\mathrm{a}} \pm 1,6$ & $72,3^{\mathrm{ab}} \pm 0,9$ \\
\hline 7 & $68,6^{\text {defg }_{ \pm 2,0}}$ & $64,5^{\mathrm{fg}} \pm 1,9$ & $68,3^{\text {defgh }_{11,0}}$ & $67,0^{\text {cdef }_{ \pm}}+4,0$ & $66,8^{\mathrm{fg}} \pm 2,0$ & $68,1 \mathrm{~cd} \pm 2,0$ \\
\hline 8 & $40,0_{ \pm 3,4}^{j_{1}}$ & $38,9^{j} \pm 0,8$ & $40,8^{j_{j}} \pm 2,8$ & $38,1^{\mathrm{h}} \pm 0,8$ & $37,6^{j} \pm 0,3$ & $39,1^{\mathrm{g}} \pm 2,1$ \\
\hline 9 & $39,8^{j_{ \pm}} 3,3$ & $38,4^{\mathrm{j}} \pm 0,7$ & $40,1^{\mathrm{j}} \pm 2,2$ & $39,0^{\mathrm{h}} \pm 0,3$ & $38,0_{ \pm 0,5}^{j}$ & $39,3^{g} \pm 1,7$ \\
\hline 10 & $72,0^{\text {abcde }} \pm 1,5$ & $71,9^{\mathrm{abc}} \pm 1,1$ & $72,3^{\mathrm{abc}} \pm 1,6$ & $72,0^{\mathrm{ab}} \pm 2,0$ & $70,6^{\text {abcde }} \pm 1,4$ & $72,0^{\mathrm{abc}} \pm 1,0$ \\
\hline 11 & $71,1^{\text {abcde }} \pm 3,0$ & $72,2^{\mathrm{abc}} \pm 1,2$ & $73,4^{\mathrm{ab}} \pm 1,9$ & $72,3^{\mathrm{ab}} \pm 1,7$ & $69,5^{\text {bcdefg }} \pm 2,1$ & $71,1^{\mathrm{abc}} \pm 2,3$ \\
\hline 12 & $63,2^{\text {hi }} \pm 1,7$ & $61,3^{\text {hi }} \pm 1,1$ & $67,8^{\mathrm{fgh}} \pm 3,7$ & $66,6^{\mathrm{def}_{ \pm}}+1$ & $61,6^{\mathrm{h}} \pm 0,6$ & $62,7^{\mathrm{ef}} \pm 1,9$ \\
\hline 13 & $73,2^{\text {abcd }} \pm 1,3$ & $73,3^{\mathrm{ab}} \pm 1,2$ & $74,2^{\mathrm{a}} \pm 0,9$ & $71,4^{\mathrm{ab}} \pm 1,5$ & $70,5^{\text {abcdef }} \pm 2,1$ & $72,6^{\mathrm{ab}} \pm 1,5$ \\
\hline 14 & $67,9^{\text {efgh }} \pm 3,1$ & $71,6^{\mathrm{abc}} \pm 1,0$ & $71,3^{\text {abcde }} \pm 0,9$ & $71,1^{\mathrm{abc}} \pm 1,7$ & $71,4^{\text {abcd }} \pm 1,2$ & $71,2^{\mathrm{abc}} \pm 1,4$ \\
\hline 15 & $70,0^{\text {bddef }} \pm 2,9$ & $71,3^{\mathrm{abc}} \pm 1,0$ & $71,6^{\mathrm{abcd}} \pm 0,6$ & $70,6^{\mathrm{abcd}} \pm 1,3$ & $71,7^{\mathrm{ab}} \mathrm{c} \pm 1,8$ & $71,4^{\mathrm{abc}} \pm 2,3$ \\
\hline 16 & $72,7^{\text {abcde }} \pm 1,4$ & $71,4^{\mathrm{abc}} \pm 1,8$ & $73,5^{\mathrm{ab}} \pm 0,8$ & $72,1^{a b} \pm 1,1$ & $72,3^{\mathrm{ab}} \pm 1,0$ & $72,7^{\mathrm{ab}} \pm 0,9$ \\
\hline 17 & $69,7^{\text {def }^{\prime}} \pm 2,7$ & $68,9^{\mathrm{cde}^{2}} \pm 2,1$ & $70,5^{\text {bcdef }} \pm 1,1$ & $68,3^{\text {bcdef }} \pm 2,2$ & $67,9^{\text {defg }_{ \pm}} \pm 1,3$ & $71,4^{\mathrm{ab}} \mathrm{c} \pm 2,3$ \\
\hline 18 & $75,1^{\mathrm{a}} \pm 0,6$ & $71,3^{\mathrm{abc}} \pm 1,3$ & $72,6^{\mathrm{abc}} \pm 2,5$ & $73,2^{a} \pm 1,9$ & $71,8^{\mathrm{abc}} \pm 1,3$ & $73,1^{\mathrm{a}} \pm 1,6$ \\
\hline 19 & $71,6^{\text {abcde }} \pm 1,2$ & $70,9^{\text {abcd }} \pm 2,1$ & $69,9^{\text {cdefg }_{ \pm 2,1}}$ & $64,4^{\mathrm{f}} \pm 3,7$ & $68,5^{\text {cdefg }} \pm 2,2$ & $68,8^{\mathrm{bcd}} \pm 2,2$ \\
\hline 20 & $69,6^{\text {cdef }^{\prime}} \pm 3,8$ & $71,4^{\text {bcde }} \pm 3,2$ & $68,1^{\mathrm{efgh}} \pm 1,5$ & $66,3^{\text {ef }} \pm 1,5$ & $67,1^{\text {efg }} \pm 0,9$ & $70,4^{\text {abcd }} \pm 1,6$ \\
\hline 21 & $69,8^{\text {cdef }} \pm 1,5$ & $72,0^{\mathrm{abc}} \pm 1,0$ & $67,3^{\mathrm{fgh}} \pm 1,2$ & $68,6^{\mathrm{bcde}} \pm 2,3$ & $66,1^{g} \pm 2,6$ & $70,3^{\text {abcd }} \pm 1,4$ \\
\hline 22 & $73,5^{\text {abcd }} \pm 1,0$ & $73,6^{\mathrm{ab}} \pm 1,3$ & $73,0^{\mathrm{abc}} \pm 1,1$ & $71,6^{\mathrm{ab}} \pm 1,2$ & $71,3^{\text {abcd }} \pm 1,9$ & $71,8^{\mathrm{abc}} \pm 2,1$ \\
\hline 23 & $74,0^{\mathrm{abc}} \pm 1,0$ & $71,2^{\mathrm{abc}} \pm 1,3$ & $71,7^{\mathrm{abcd}} \pm 1,1$ & $72,9^{\mathrm{a}} \pm 1,6$ & $70,9^{\text {abcd }} \pm 1,9$ & $71,9^{\mathrm{abc}} \pm 1,7$ \\
\hline 24 & $73,8^{\mathrm{abc}} \pm 5,6$ & $67,7^{\mathrm{def}} \pm 1,9$ & $67,1^{\mathrm{gh}} \pm 1,8$ & $65,6^{\mathrm{ef}} \pm 2,7$ & $68,9^{\text {bcdefg }_{ \pm}}+1,7$ & $62,3^{\mathrm{f}} \pm 3,2$ \\
\hline 25 & $65,8^{\text {fgh }} \pm 1,3$ & $66,4^{\mathrm{efg}_{ \pm} 2,4}$ & $62,3^{i} \pm 1,9$ & $58,5^{\mathrm{g}} \pm 2,8$ & $60,6^{\mathrm{hi}} \pm 2,5$ & $61,4^{\mathrm{f}} \pm 3,8$ \\
\hline
\end{tabular}

*Mean followed by the same letter did not differ from each other at a significance level of $5 \%$ by the Tukey test. 
The weekly average shows that the values for the analyzed months are very similar, which shows that there was a standard for the established time. Comparison of these points with the NBR 10151/00 values can be seen in Figures 3-6.

Figure 3 - Urban noise in mixed-use areas containing commercial and institutional buildings

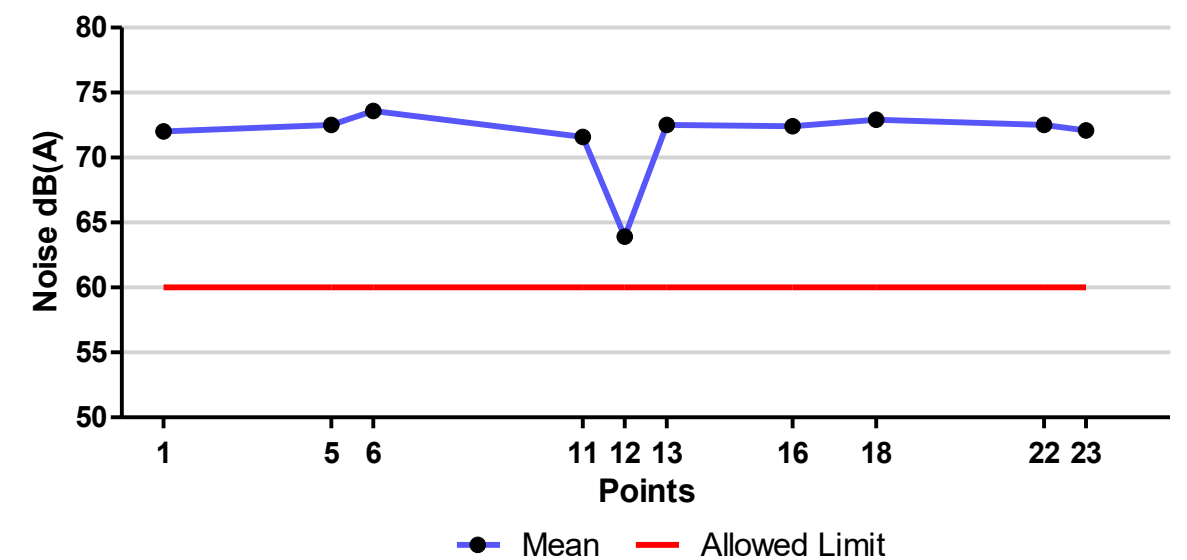

Sampling points $1,5,6,11,12,13,16,18,22$, and 23 are located in mixed-use areas containing residences, shops, schools, hospitals, and large roads. There is also a high turnover of people due to the nearby shops and schools, which leads to a higher amount of traffic. Figure 3 shows that all of these sampling points are above the NBR 10151/00 permitted limit of $60 \mathrm{~dB}(\mathrm{~A})$ for the daytime. Heavy vehicle traffic, caused in part by a large number of people visiting shops, is the most influential source of high noise levels in the area. Brito (2017) identified that in areas near the main avenues the noise level is approximately $10 \mathrm{~dB}(\mathrm{~A})$ above that allowed by NBR 10151/00, corroborating the results shown in Figure 3.

Figure 4 - Urban areas that are strictly residential or used for hospitals or schools

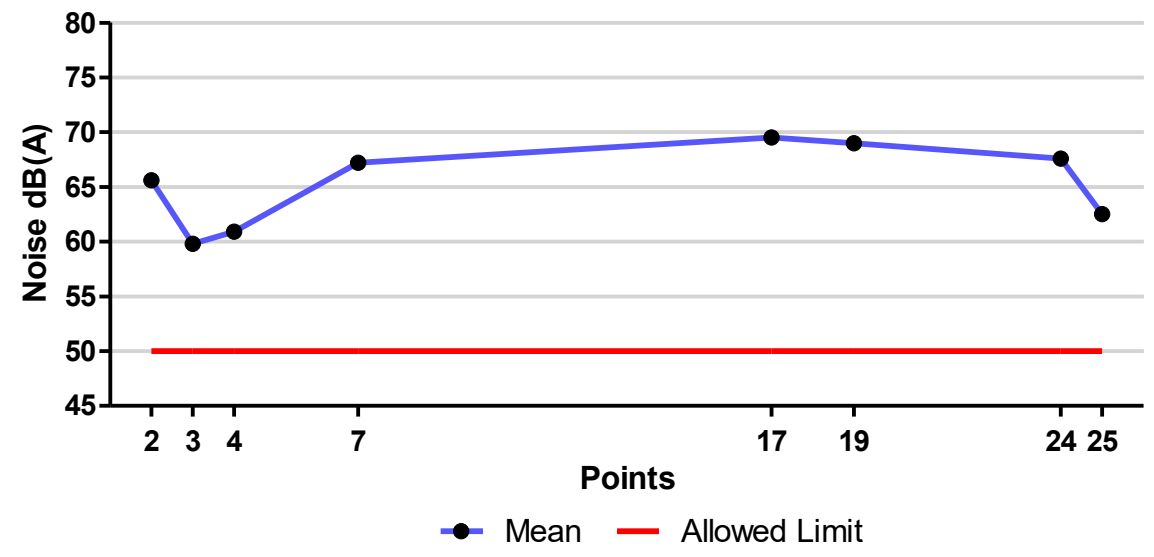

Points 2, 3, 4, 7, 17, 19, 24, and 25 were measured in urban areas that are strictly residential or used for hospitals or schools, where the maximum allowed level is $50 \mathrm{~dB}(\mathrm{~A})$. Point 3 is located between 4 schools and a kindergarten. During the measurement time period, the elementary school level has lessons until 11:15 and the middle school-high school level until 12:20, which increases the circulation of vehicles 
and people, and contributes to an increase in noise level of 10 decibels above that allowed by the NBR 10151/00 (Figure 4). In other points, the noise levels of the residential areas are all above that allowed by NBR 10151/00. Almeida et al. (2016) performed noise measurements in a mixed-use zone and detected values ranging from 65 to $70 \mathrm{~dB}(\mathrm{~A})$. Even though there is a hospital in this area, the noise level is well above that allowed by NBR 10151/00. Additionally, all of the points measured by Penido et al. (2014) near schools and hospitals were above the established limits.

Figure 5 - Noise levels in predominantly residential areas

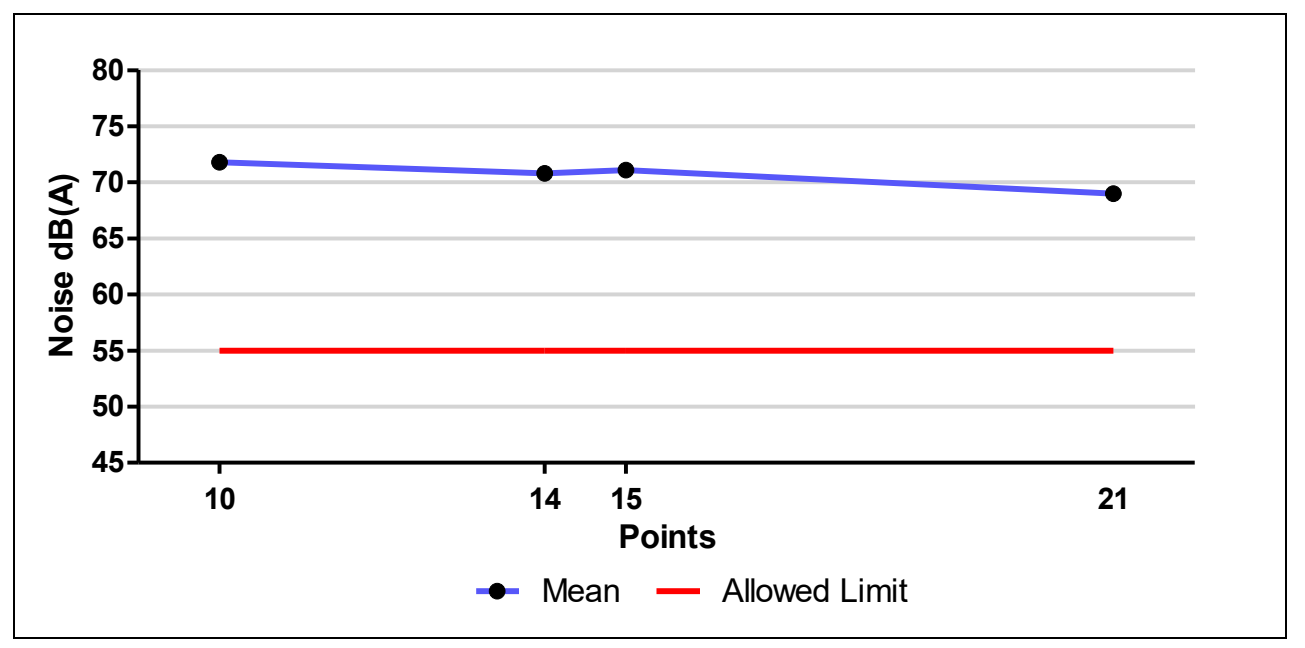

Points $10,14,15$, and 21 are points located in predominantly residential areas which, according to NBR 10151/00, have a maximum allowed limit of $55 \mathrm{~dB}$ for the measurement time (Figure 5). The most critical points are 10 and 15, as they are neighborhoods intersected by two-way, high traffic routes that provide vehicular access to the central part of the city. As a result of this, these points present high noise levels. As the city of São Luís undergoes major changes in traffic, neighborhoods tend to exhibit increased noise levels (Bessa \& de Lima, 2017). Measures to reduce traffic noise should be taken to prevent this problem from spreading to other regions.

Figure 6 - Site areas and farm

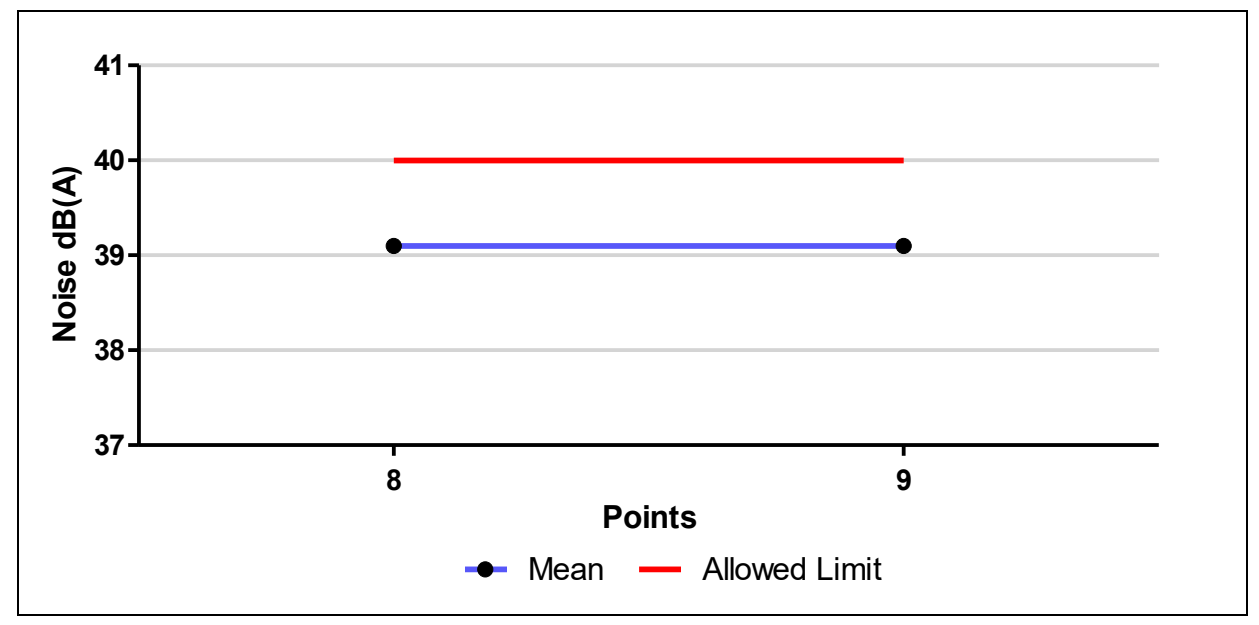


Points 8 and 9 are very different from the others since they were measured in an area of environmental preservation. In the surroundings of this area there is a great circulation of vehicles as it is a place of access to several well-populated neighborhoods; however, it also contains a park for recreation activities. The purpose of these sampling points was to verify the extent to which vehicle traffic noise can be reduced with green spaces. The two points measured in this area are within the allowed NBR 10151/00 limit of $40 \mathrm{~dB}(\mathrm{~A})$.

According to Szeremeta and Zannin (2013), green spaces can improve residents' quality of life, and their conservation is of paramount importance to public health.

The analysis of the data showed homogeneity for the established time, which can be confirmed by the coefficient of variation (CV) as shown in Figure 7.

Figure 7 - Mean and coefficient of variation for the six months of monitoring

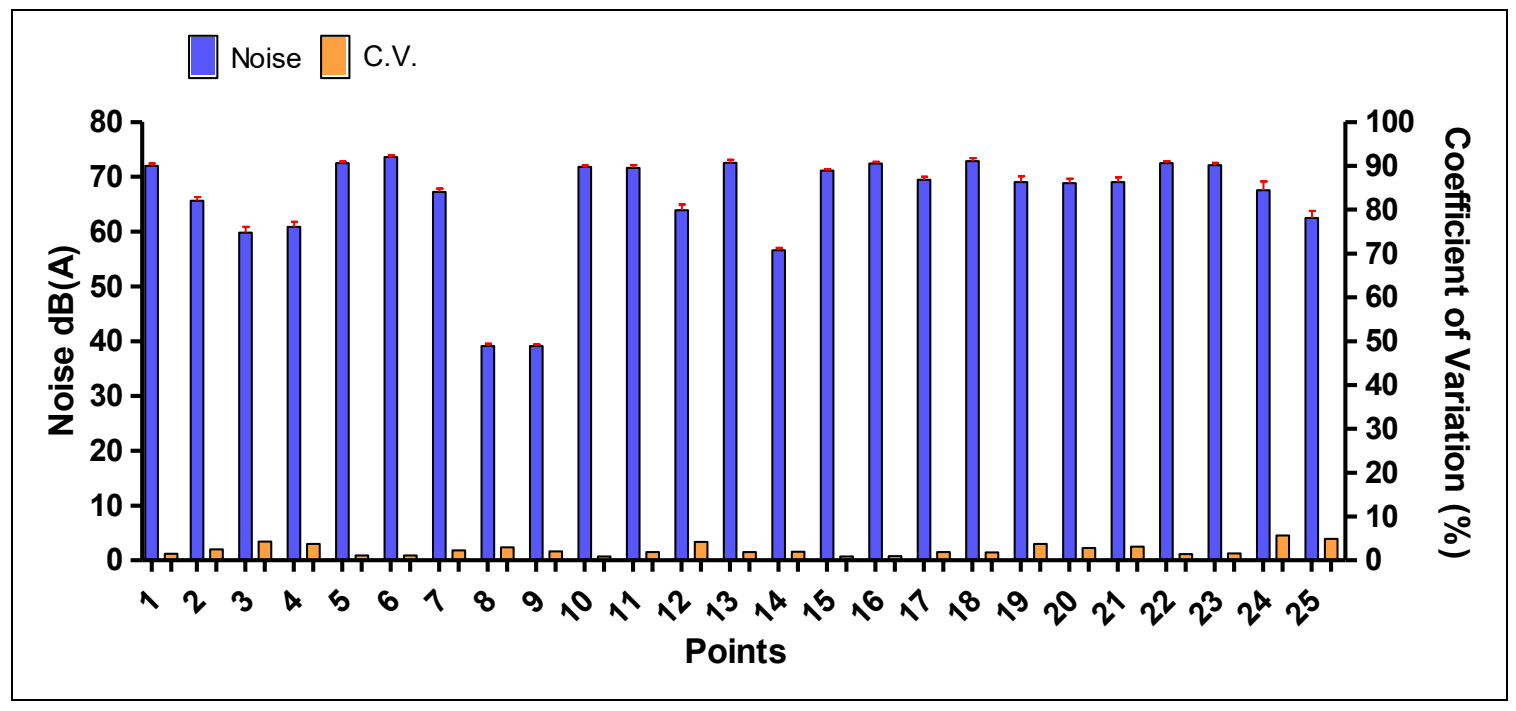

The pattern of noise emission in the city over the study's monitoring period is characterized by a very low coefficient of variation.

\section{Conclusions}

Six months of noise monitoring in the city of São Luís revealed that the population is exposed to high levels of noise, predominantly in mixed-use urban areas comprised of residences, large commercial centers, and high traffic roads. Data analysis indicated that vehicular traffic is the source that most contributes to the high noise indexes observed in the study area. Traffic levels in the city of São Luís city are also influenced by the nearby municipalities of Paço do Lumiar, Raposa, and São José of Ribamar.

Only 2 of the 25 points monitored were within the limits established by NBR 10151/00. As these points were collected within an area of environmental preservation, the importance of vegetation in reducing urban noise levels is evident. This demonstrates the necessity of incorporating measures to preserve vegetation in the urban planning process of large cities. 


\section{Acknowledgments}

This work was supported by the University Ceuma - UNICEUMA; FAPEMA (Process UNIVERSAL00503/15). PCMV and DRS are grateful to Prof. Dr. Sérgio Fernando Saraiva da Silva (UNICEUMA, Brazil) for all help and friendship.

\section{References}

ABNT. (2000). NBR 10.151. Contributions to Psychological Acoustics-Results of the eight Oldenburg Symposium on Psychological Acoustics. Retrieved from http://www.semace.ce.gov.br/wp-content/uploads/2012/01/Avaliação+do+Ruído+em+Áreas+ Habitadas.pdf

ALVES, J., SILVA, L., \& REMOALDO, P. (2015). The Influence of Low-Frequency Noise Pollution on the Quality of Life and Place in Sustainable Cities: A Case Study from Northern Portugal. Sustainability, 7(10), 13920-13946. https://doi.org/10.3390/su71013920

BACHMANN, R. K. B., CARNEIRO, L. M., \& ESPEJO, M. M. D. S. B. (2013). Evidenciação de informações ambientais: proposta de um indicador a partir da percepção de especialistas. Revista de Contabilidade e Organizações, 7, 36-47. https://doi.org/10.11606/rco.v7i17.56666

BRITO, L. A. P. F. de. (2017). A utilização de mapas acústicos como ferramenta de identificação do excesso de ruído em áreas urbanas. Engenharia Sanitaria e Ambiental, (0). https://doi.org/10.1590/s1413-41522017152589

DA PAZ, E. C., FERREIRA, A. M. C., \& Zannin, P. H. T. (2005). Comparative study of the perception of urban noise | Estudo comparativo da percepção do ruído urbano. Revista de Saude Publica, 39(3).

EC. (2002). Directive 2002/49/EC of the European parliament and the Council of 25 June 2002 relating to the assessment and management of environmental noise. Official Journal of the European Communities, 189(12), 12-25.

GUEDES, I. C. M., \& BERTOLI, S. R. (2014). Mapa acústico como ferramenta de avaliação de ruído de tráfego veicular em Aracaju - Brasil. PARC Pesquisa Em Arquitetura e Construção, 5(2), 40-51. Retrieved from https://periodicos.sbu.unicamp.br/ojs/index.php/parc/article/viewFile $/ 8634537 / 2458$

HANSON, D. I., DONAVON, P., JAMES, R., MONISMITH, C., ANDERSON, D., DAVIS, R., \& SWANLUND, M. (2005). Tire/pavement noise characteristics of HMA pavements. Asphalt Paving Technology: Association of Asphalt Paving Technologists-Proceedings of the Technical Sessions, 74, 1005-1041. 
IBGE. (2017). IBGE - Instituto Brasileiro de Geografia e Estatística. Retrieved from https://mapas.ibge.gov.br/tematicos

J. C. DE A. BESSA, A. M. M. DE LIMA, J. de A. S. J. (2017). Avaliação da poluição sonora e zoneamento de ruído em área piloto no município de Manaus/AM. ENGEVISTA, 19(2), 409-426. https://doi.org/10.22409/engevista.v19i2.852

LACERDA, A., FIGUEIREDO, G., MASSAROLO NETO, J., \& MARQUES, J. M. (2010). Achados audiológicos e queixas relacionadas à audição dos motoristas de ônibus urbano. Revista Da Sociedade Brasileira de Fonoaudiologia, 15(2), 161-166. https://doi.org/10.1590/S151680342010000200003

LACERDA, A. B. M. DE, MAGNi, C., MORATA, T. C., MARQUES, J. M., \& ZANNIN, P. H. T. (2005). Ambiente Urbano e Percepção da Poluição Sonora. Ambiente \& Sociedade, VIII(2), 1-13. https://doi.org/10.1590/S1414-753X2005000200005

MENDONÇA, A. B. D., SURIANO, M. T., LUCAS DE SOUZA, C., \& VIVIANI, E. (2013). Classes de quadras urbanas determinadas pelos níveis de ruídos. Revista Brasileira de Gestão Urbana (Brazilian Journal of Urban Management, (2), 63-77. https://doi.org/10.7213/urbe.05.002.SE05

PENIDO, EUSTÁQUiO COUTO AZEVEDO, F. R., \& SOUZA, J. H. de. (2014). Poluição sonora: aspectos ambientais e saúde pública. Revista Das Faculdades Integradas Vianna Júnior, 2(1), 1-5. https://doi.org/10.1007/s13398-014-0173-7.2

RAVINDER, L., \& BELACHEW, M. G. (2014). Urban Noise in a Metropolitan Towns. Urban Noise in a Metropolitan Town, (October), 1-13.

SZEREMETA, B., \& ZANNIN, P. H. T. (2013). A importância dos parques urbanos e áreas verdes na promoção da qualidade de vida em cidades. Raega - O Espaço Geográfico Em Análise, $29,177$. https://doi.org/10.5380/raega.v29i0.30747

W. L. DE AlmEIDA, V. B. CAMPOS, R. DE M. R. NETO, P. F. H. SAMPAIO, E. D. RIBEIRO, J. F. R. C. (2016). Avaliação do nível de ruído nas proximidades do Hospital Estadual de Laranjal do Jari (Amapá). Saúde \& Meio Ambiente, 5(1), 43-53. https://doi.org/10.24302/sma.v5i1.796

World Health Organization -WHO. (2011). Burden of disease from environmental noise. World Health, 1-105.

ZANNIN, P. H. T., CAliXTO, A., DINIZ, F. B., FERREIRA, J. A., \& SCHUHLI, R. B. (2002). Incômodo causado pelo ruído urbano a população de Curitiba, PR. Revista de Saude Publica, 36(4), 521-524. https://doi.org/10.1590/S0034-89102002000400020 